Journal of World Englishes and Educational Practices (JWEEP)

ISSN: $2707-7586$

DOI: $10.32996 /$ jweep

Journal Homepage: www.al-kindipublisher.com/index.php/jweep

\title{
Modified British Parliamentary Debate Technique in Teaching Speaking to Indonesian EFL
} Learners

\author{
Rafi'ah Nur $^{1} \square$ Ammang Latifa $^{2}$ and Masriani $^{3}$ \\ ${ }^{123}$ Universitas Muhammadiyah Parepare, Indonesia \\ $\square$ Corresponding Author: Rafi'ah Nur, E-mail: rafiahnur@yahoo.com
}

ARTICLE INFORMATION ABSTRACT

Received: 08 October 2021

Accepted: 25 October 2021

Published: 08 November 2021

DOI: 10.32996/jweep.2021.3.11.1

\section{KEYWORDS}

Speaking skills, interest, modified British parliamentary debate.
For English language learners, speaking is an essential skill that should be achieved. By practicing continuously, they can become trained and skilled. To support their proficiencies and competencies, they also should master the language subskills: pronunciation, structure, and vocabulary. The teachers, therefore, should facilitate their students by applying appropriate techniques of language learning in the classroom so that their students can speak English quickly. Through this study, the researchers managed an effective teaching technique for speaking class by implementing a modified British Parliamentary Debate to train the students' speaking skills. This study, therefore, projected to find out whether or not the use of the Modified British Parliamentary Debate technique in teaching speaking can increase their speaking skill. This study also aims to determine whether or not the students are interested in learning to speak through the modified British parliamentary debate. The study applied the quasi-experimental method with a nonequivalent control group design. The subjects of the study were students of Madrasah Aliyah Negeri Enrekang, Indonesia. The population of the research was 64 students. The researchers grouped the students into two groups. There were 32 students in group one and 32 students in group two. The researchers assigned both groups to the same activities in pretest and posttests but different treatments of teaching techniques. The researchers gave a modified British parliamentary debate model for the experimental group and a small group discussion for the control one. The instruments of the research were an oral speaking test and a questionnaire. The results of data analysis exhibited a significant improvement in the students' speaking skills after the treatments. The result of hypothesis testing showed that the t-test value (2.087) was higher than the t-table value (2.000) at the level of significance 0.05 and the degree of freedom 62. Moreover, based on the questionnaire, this study found that the students were interested in learning the speaking skill through modified British Parliamentary debate. In short, implementing the modified British parliamentary debate in teaching speaking can develop the students' speaking skills and encourage the students to learn speaking ability.

\section{Introduction}

To be competitive in this era of 4.0, the English students or learners should be skilled in English, especially speaking skills. Richards (2008) claimed that mastering speaking skills were a priority for second-language or foreign-language learners. Speaking is one way of exploring information through oral communication. The speaker must have the capability to think of an idea then express whether they started a conversation in response to the preceding speaker. Speaking should be learned and should be practiced in the classroom. Therefore, the teacher must facilitate the students to make them communicate in English easily. To master speaking skills, students should practice continuously. Moreover, they should know the English sounds, structure, and vocabulary.

Copyright: (c) 2021 the Author(s). This article is an open access article distributed under the terms and conditions of the Creative Commons Attribution (CC-BY) 4.0 license (https://creativecommons.org/licenses/by/4.0/). Published by Al-Kindi Centre for Research and Development, London, United Kingdom. 
Speaking skills seem intuitively more important than the three other skills: listening, reading, and writing (Ur, 2009). Therefore, their speaking skills should be more dominant to help the students to develop their competence in learning English. Without speaking capability, the students cannot do English communication, perform their feeling, idea, and emotions. The students also cannot get their potency and may be discouraged from having a chance to learn. The inappropriate boring methods and techniques may cause these problems. For example, the teachers used the traditional methods that made the English class atmosphere looks boring.

As indicated by initial observations, students' speaking skill in class XI Madrasah Aliyah Negeri Enrekang was still weak. Most of them had a score under the minimum learning mastery standard. The big problem that they faced was pronunciation, grammar, and vocabulary that affected their speaking skill. In this preliminary observation, the researchers also get information dealing with the factors which caused these problems. The researchers identified that the most common cause was the inappropriate methods applied by the teachers in the classroom. They are constrained in fewer variation methods. Sometimes students received a lesson with less attractive learning methods. These have been encountered by some experts like Goh (2007), who suggested developing speaking ability utilizing syllabus design, the principle of teaching, types of task and material, and speaking assessment.

To make the instructional process more effective and exciting, the researchers tried to propose the Modified British Parliamentary Debate as an effective technique to boost students' speaking and expressing ideas in English. This technique is believed to provide opportunities for students to be involved in discussions. The students can have the audacity and critical thinking and are anxious to take responsibility for their learning. Even though it allows the intensive role of students as more significant. It does not imply that the instructor in the classroom is not taking parts. Nur and Syarifuddin (2018) noted that the teacher should be facilitating, modest, attentive, empathetic, accessible, and ready for extra assistance.

A teacher plays roles as a planner, facilitator, and adviser in the learning process in the classroom. They should manage the classroom so that the learners can involve themselves without anxiety. Martin (2019) claimed that English teachers should apply proper techniques to help their students neutralize their feelings. He also suggested encouraging them to have the confidence to make mistakes to acquire the necessary communication skills (Martin, 2019).

This study, therefore, aimed at solving the students' problem by enrolling them in a language learning process by applying the modified British Parliamentary debate. The specific objective was to investigate whether using the Modified British Parliamentary Debate technique can increase the speaking skill of Madrasah Aliyah Negeri Baraka students. Besides, this study described the students interested in learning to speak through the modified British parliamentary debate.

\section{Literature Review}

\subsection{Teaching Speaking}

Speaking is one way to express ideas and transmit messages orally. Therefore, teaching speaking should be based on the communicative approach to enable students to communicate in real communication. The communicative approach in language teaching begins at a theory of language as communication. The purpose of language teaching is to promote students' competencies in communication. Richard and Rodger (1999) claimed that the communicative approach is a set of convictions that contained a countercheck of what elements of language to teach and a shift in concerns in teaching.

Some factors can determine the students to learn to speak. Factors like learners themselves, teachers, teaching methods, and power distance may influence the students' motivation to speak (Thai, 2018). The use of exciting media such as audiovisual aids also affects learning (Amaluddin et al., 2018). Badaruddin et al. (2019) claimed that by utilizing the right media like laptops, projectors, or LCDs to present learning materials, the students would learn more interactively and excitingly. Besides, Latifa et al. (2019) also noted that appropriate media could influence the students' speaking skills and motivation. Therefore, the teacher should make their lesson enjoyable by implementing communicative approaches to make the students not feel sleepy and bored during the learning process (Harmer, 2001).

Teaching speaking should accommodate various methods that integrate different types of language inputs and outputs. The students at all proficiency levels obtain benefits from such variety. Some research has found that the various teaching methods are more encouraging and have more potential to earn in energetic language learning. These methods help students to learn speaking skills.

\section{Information Gap Activity}

The information gap is the speaking activity that involves two speakers taking part in the information that makes up the whole. There is a gap between them because of the different information they share (Harmer, 2001:88). Among various communicative approach activities, this activity is more effective for the students who want to practice speaking in the classroom (Ismaili \& Bajrami, 
2016). Information gap also brings the learning activities into enjoyable activities. Irona and Ratmanida (2018) claimed that the information gap makes the students relish the activities in the classroom because they are motivated to communicate with their mates.

\section{Role Play}

In a role-play, the students are engaged in activities where they can imagine things in a different condition they set. Harmer (2007) stated that these activities bring students into imagining different situations and ask them to act accordingly. Murcia (2001: 106) stated that role-play is particularly corresponding for training the social-cultural variations in speech acts, such as complimenting and complaining.

\section{Discussion}

In a discussion, students need time to converge their ideas before the discussion is conducted. The ability to give a spontaneous response and express opinions is a challenge in their performance. That is why the teacher must give them preparation to build a case before they perform a discussion (Harmer 2007). Murcia (2001) suggested that, in these activities, they discuss a consecutive topic in order to discover a solution and a response. However, the students need to be clear about what they will be discussing, what rationale behind the discussion, and what the expected outcome is.

Many courses are designed related to speaking skills. It grows from time to time. Through this research, the writer puts some material related to speaking skills through modified British Parliamentary debate.

\section{Expressing of Asking for and Giving Opinion}

In the expression of asking and giving an opinion, students express their opinion about something they ponder or believe about it. To communicate, we sometimes need others' ideas to solve our problems because we find them hard to solve. Expressions like what do you think of, what is your opinion, in my opinion, I think... are expressions that we can use to ask someone's opinion and give our opinion to someone else. We need to use these expressions in a discussion activity (Bashir 2014)

\section{Expressing of agreement and disagreement}

Expression of agreement and disagreement allows the students to express their position on something. The example of expressions that we can use to express agreement and disagreement with someone, such as I agree with you, absolutely, that's so true, I don't think so, and I am not so sure about that.

The writers then infer that those components of a speaking assessment are necessary to discuss in this study because they can help the researchers discover whether the students' success in speaking. Indeed, Ur (2009) characterizes the success in speaking activity into

a. learners activeness to talk a lot where they occupy as much of the specified period as possible,

b. Even participation because a minority of talkative participants does not dominate the class discussion,

c. high motivation of the learners, and

d. acceptable level of language.

So, the success of speaking assessment can be shown when the students can express themselves in utterances related to speaking competence. They are grammar, vocabulary, pronunciation, discourse, and strategic competence (Latifa et al., 2015).

\subsection{The British Parliamentary Debate as a Technique in Teaching Speaking}

The debate is the activity of presenting ideas or opinions about a problem with two or more points of view. James (2003) defined the debate as the process of disputing assertions in a condition where an adjudicator must decide the outcome. Thus, a debate is an activity that almost does not exist without argument. D'Cuz (2003) states that debate is about persuasion. People are induced by several tools, rational and irrational, logical and illogical, depending on the cultural context and local customs. The debate is a particular form of argument to arbitrate differences performed in the form of the team (Smith 2011). So, through this research, it can be concluded that debate is the process of presenting an opinion where an adjudicator must decide the outcome. Debates do not contain separated individual speeches which are isolated from each other. It is a group activity, and each speaker must be respected in their team mission and their own mission.

British Parliamentary Debate is convinced to be able to give opportunities for the students to be involved in the discussion. The students can have courage and critical thinking and want to take liability for their learning. Although it considers students' roles more necessary, it does not imply that the teacher in the classroom does not follow the process because a teacher has roles as a planner, assistant, and director in the learning process. 
The form of the British Parliamentary debate is worlds-style debating. It is the currently most popular format used in schools and universities' debating championships every year all over the world (Smith 2011). In this debate-style, there are four teams where each of the two speakers will have a controversy on a motion. Two teams play roles on the government or affirmative side, the opening government and the closing one. Two other teams are standing on disagreements. Or oppositions, the opening opposition and the closing one (Morgan 2011).

The British Parliamentary debate-style possesses some basic rules. Smith (2011) describes procedures of this debate style.

1) Seven-minute speeches.

2) A protected time in the first and last minutes for no information points may be made during this period.

3) Information points must be offered for three minutes of unexposed time while the other party member is speaking.

An obvious internal structure should be possessed by the delivered speeches. Often it is best to start by striking the previous speaker's argument from the other point of view. It makes it the audience and the judges much easier to attend the speech. Smith (2011) describes the structure of the debate and the roles of the speakers:

1) The duties of the prime minister (first member of the opening government team) are determining the reasons for the debate, conveying his own substantive material, and marking the argument that will be delivered by the partner.

2) The job of the opposition leader (first member of the opening opposition team) is defining the reason for the opposition, defying the first government, conveying its own substantive concept, marking the argument that the partner will deliver, and do not challenge the definition if the speaker is resentful.

3) The roles of the deputy prime minister (second member of the opening government) are defying the first opposition, conveying their own substantive concept by using the label that partners give to it, and making hints back to the partner's idea.

4) The duties of deputy opposition leader (second member of the opening opposition) are defying arguments of the first government team with a special responsibility to refute the second government, conveying own substantive material concept by using the label that partners give to it, and making hints back to partner's idea.

5) The roles of the government member (first member of the closing government team) are delivering own substantive material, not necessary to say the word 'extension,' rebutting the speakers' arguments with particular responsibility to argue the second opposition.

6) The opposition member (first member of the closing opposition team) is responsible for disputing the speakers' arguments with particular responsibility to deal with the extension from the third government. Conveying own substantive material, not necessarily in delivering an 'extension.

7) As the second member of the closing government team, the government whip is assigned to summate for the speaker's side, not ought to offer new material (subject to the discussion above).

8) The duties of the opposition whip (second member of the closing opposition team) are summating for the speaker's side and definitely, definitely offering no new material.

This research used the British parliamentary debate. However, in the implementation, the researchers made some modifications, such as in case building and adjudication. The nature timing of case building in BP debate is 15 minutes, but the researchers add the time building into 30 minutes. While in adjudication session, the number of adjudicators is only three-person in the preliminary session and five adjudicators in the grand final round. Nevertheless, in this research, the researchers empower all the members of the other group as the adjudicator to actively practice their speaking skills in every meeting.

\subsection{Interest}

Experts in various definitions have defined the interest. In Dictionary.com, interest is defined as the feeling of a person whose attention, concern, or curiosity is particularly engaged by something. Hornby (2010) defined interest as an activity or subject that you do or study for pleasure that one spends the time doing or studying. Interest is defined by Ur (2009) as a type of external encouragement, as a district from the desire to learn of its own shake or interest in the task that raises extrinsic motivation.

Fisher (1930) asserted that interest refers to the type of matters that we respect and savor. The researchers can infer that interest is a manner that constantly accompanies one's concerns in choosing an object of interest. It is a sensation that establishes the things that are rated for a person. In addition, it is a certain pleasure, concern, or curiosity that directs one's behavior for a particular purpose. Interest is the readiness or eagerness to pay attention to be attentive or study something for the pleasure of someone spending time doing it. In this research, the interest will be investigated on how the students' interests are attracted in learning English speaking skills with applying the British Parliamentary debate model. 
There are various factors influencing students' interest in the teaching and learning process. They are pleasure, concern, and curiosity. Ur (2009) states that a general underlying orientation has to be built up when the course begins. However, in clear classroom learning, a more important factor is whether the given task is considered interesting. It is to generate interest; perhaps the teacher invests most of the effort and gets the most immediate and real play-off in terms of student fun, attention, and curiosity. Interest, in short, is a student's desire and need to learn the driving forces that make him work hard and pay attention. The teacher's determination that students should learn is an important contribution to this, as is the impulse and taste of progress must also be passed down from the teacher (Haycraft 1978).

From Dictonary.com, we can find the definition of pleasure as the excitement or satisfaction acquired from what is to someone's liking, gratification, and delight. While concern is defined as a matter that engages a person's attention, interest, or care or that affects a person's welfare or happiness. This concern is also related to the focus rate of the students toward the material they learn. Thus, curiosity is curiosity and desire to learn or know about anything; inquisitiveness.

\section{Methodology}

This study applied the quasi-experimental design with a nonequivalent control group design. Gay et al. (2012) explained that in the nonequivalent control group design, two or more treatment groups are given a pretest, treatments, and a postest. One group is given the experimental treatment, and the other group is given the control treatments. The researchers assigned teaching speaking through the modified British Parliamentary Debate technique to the experimental group and discussion technique to the control one.

Thus, this study examined the influence of the modified British Parliamentary debate techniques in teaching speaking as the independents variable to the students speaking ability as the dependent variable. The researchers also investigated the students' interest in English speaking through the modified British Parliamentary Debate technique.

The subjects of this research were 740 students of Madrasah Aliyah Negeri Enrekang from grade X to XII. The survey sample was grade $\mathrm{XI}$, who were selected purposively by considering that the material for the class suited the techniques to be used. There were 64 students in this grade XI. As the type of the research design suggested, the students were grouped into groups: one as an experimental group and one as the control one. Both groups consisted of 32 students. They were assigned by random group assignment.

Gay et al. (2012) noted that this design involved random assignment of the intact group to treatment, not a random assignment. In collecting the data, the researchers distributed two instruments, namely an oral speaking test and a questionnaire. The speaking test was delivered in pretest and posttest sessions. The researchers, as observers, deliver five questions to students in both tests. The researchers chose to express giving opinions as topics of the test. The students expressed their points of view on the school environment and smoking. Meanwhile, a questionnaire was given to find out students' interests through the implementation of a modified British parliamentary debate technique. There were 30 questions to answer whether or not the students were interested in learning speaking English through the modified British Parliamentary debate model.

The researchers analyzed the data by using quantitative analyses. The speaking test results were scored and rated by using the Latifa rubric (Latifa et al., 2015). The researchers, however, analyzed the questionnaire using percentages and a Likert scale.

\section{Results and Discussion}

This section discusses the findings of the research and the interpretation of them. The findings were obtained from the statistical analysis of students' speaking achievement from the pretest and post-test results. It also describes data from the questionnaire investigating the students' interests in the modified British parliamentary debate model in teaching speaking.

Basically, this research is supported by some previous research findings which have a relation and a different focus from others. Firstly, the study presented by Oradee (2012) concentrated on the use of three communicative activities in developing speaking skills. Secondly, the research carried out by Diep (2017) only focused on the grammar, pronunciation, and teaching method as the most impact factors to increase the quality of their English speaking skills. Thirdly, the study by Supharatypthin (2014) inspires the writer that all of the methods in developing speaking skills should be conducted by the use of the communicative approach. Fourthly, the research handled by Hasanah (2012) and Firdaus (2012) focused on general debate and Australian Parliamentary debate. The above finding shows that the researchers conducted new research which differs from the previous research projects. This study concentrates on developing speaking skills by using the modified British Parliamentary debate model. 
Based on the preliminary observation carried out to the XI grade students of Madrasah Aliyah Negeri Enrekang. The researchers found that the student's speaking skill was still weak. Most students remain had the scores under minimum learning mastery standard. The big problem they face is focusing on pronunciation, grammar, and vocabulary that affect their speaking skills. Then, the author gave the questionnaire to identify which factors constraint their less knowledge of speaking skills. The results of the questionnaire exhibited that students were constrained in fewer variation methods. That is why the researchers offered a learning model, namely, modified British Parliamentary debate. This teaching model is believed to allow students to participate in the discussion because the students can have courage and critical thinking.

\subsection{Results}

In this research, the researchers found that teaching speaking by implementing modified British Parliamentary Debate at the eleventh year students of MAN Enrekang can significantly improve their speaking ability. It is verified by the results of the t-test value that greater than the $t$-table value. In addition, It was proved that the mean score of the experimental group on the posttest is greater than the students' mean score in control one. The detailed discussion of the students' achievement is presented as follow:

\subsubsection{The students' speaking skills on the pretest}

The findings were obtained from the results of statistical analysis of students' speaking achievement from the pretest and posttest results. This part elaborates the findings and the interpretation of it. Moreover, it presents an explanation of the data obtained from a questionnaire of students' interest in the modified British parliamentary debate in teaching speaking.

This study supports some previous related research findings. Firstly, the study presented by Oradee (2012) focuses on the application of three communicative activities in bolstering the students' speaking skills. Secondly, the research carried out by Diep (2017) only focused on the grammar, pronunciation, and teaching method as the most impact factors to increase the quality of the students' English speaking skills. Thirdly, Supharatypthin (2014) study inspires the writer that all methods in developing speaking skills should be based on the application of the communicative approach. Fourthly, the research handled by Hasanah (2012) and Firdaus (2012) focused on general debate and Australian Parliamentary debate. The above finding shows that this study's researchers conducted new research that differs from the previous research findings. This research, indeed, concentrates on developing speaking skills by using a modified British Parliamentary debate model.

Based on the preliminary observation carried out to the XI grade students of Madrasah Aliyah Negeri Enrekang. The researchers found that the student's speaking skill was still low or weak. Most of the students had scores under the minimum learning mastery standard. The big problem they face is focusing on pronunciation, grammar, and vocabulary that affect their speaking skills. Then, the authors gave the questionnaire to identify which factors constraint their less knowledge of speaking skills. The result of the questionnaire exhibited that students were constrained in fewer variation methods. Therefore, the researchers offered a learning model, namely, modified British Parliamentary Debate. This technique is believed to be able to allow students to be involved in the discussion because the students can have the courage and critical thinking.

The researchers found that teaching speaking by implementing a modified British Parliamentary Debate technique at the eleventh year students of MAN Enrekang can increase the students' speaking skills. It is evidenced by the results of the t-test calculation, which is higher than the $t$-table value. It is also evidenced by the students' average score in the experimental group on the posttest, which is higher than the score of students in the control group. The detailed discussion of the students' achievement is presented as follow:

- MAN Enrekang is a school beautiful like this is school.

- MAN Enrekang has presentations academic and non-academic.

Mispronunciation: the students articulated some errors in pronouncing some English words. They found it was difficult to pronounce some English words because, regularly, they were affected by the sound structures of their mother tongue. McCarthy (2000:88-89) gave an example when words join each other in an utterance; phonemes can encounter quite a big change. A common sample is a difference between the normally oral translation of 'good evening' [gədi:vnin], and that of 'good morning' [gəbmว:nin].

In this research, the writer found some mispronunciations. Most of the final words are always pronounced long and have different intonations. Such us "MAN Enrekang is very beautiful" some students pronounced "MAN Enrekang i....s very beauti....fuuul"

Many students also made the switch of phonemes, such as a/ə/ substituted to /o/ for instance, know /nəu/ switched to /now/. 
Along with the mistakes made by the students in the pretest, the writer tries to find the problem. The researchers discovered that the student's speaking skill was still low because the students were constrained by a less variation method. Therefore, the researchers tried to overcome the students' problems by implementing a modified British parliamentary debate model in teaching speaking skills.

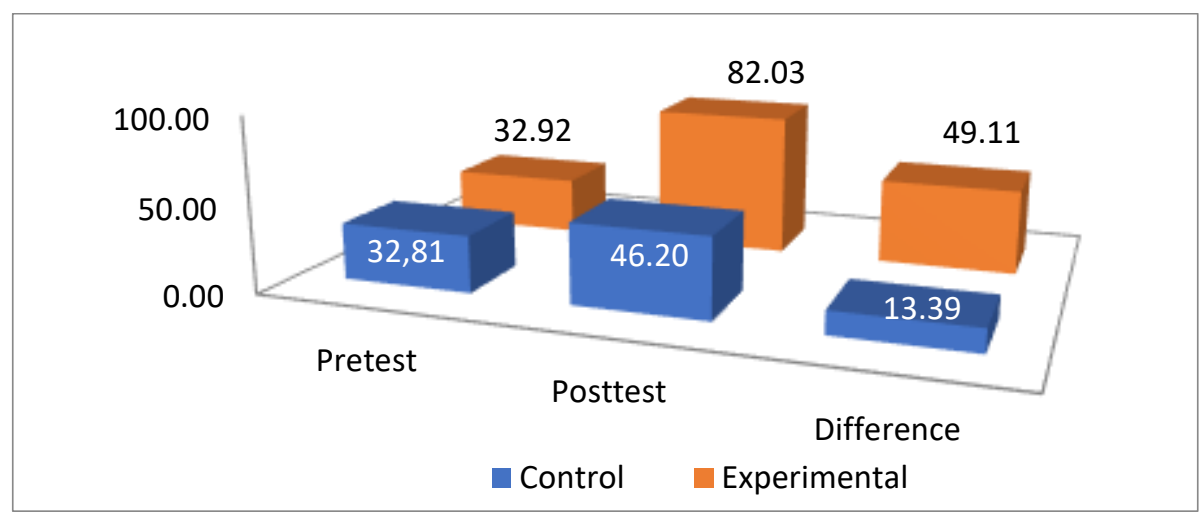

Figure 1. Description of students' scores on pretest and posttest

\subsubsection{The students' speaking skills on the posttest}

The researchers applied modified British parliamentary debate as a learning model in teaching speaking skills for eight meetings. After implementing the model, the writer found that it could increase the students' speaking skills at MAN Enrekang.

The finding showed the students' mean score and standard deviation of the students' scores in speaking skills on the posttest. In the experimental group, the students' scores improved dramatically, and the standard deviation decreased. Nevertheless, in the control group, students' post-test was also increased, but it was not significant, and the standard deviation decreased. The data indicates a significant difference between the students' scores in pretest and posttest after the treatment by implementing modified British parliamentary debate.

The above statements were supported by the frequency rate and percentage rate of the students' scores of speaking skills in the posttest. From the above finding, it can be seen that the student's achievement in the experimental group and control group increased. However, there was still one student classified as poor. It is caused by the lack of presence of the student in the learning and teaching process. She only joined in for four times meetings because she was sick.

\subsubsection{The Different mean scores of pretest and posttest}

The findings show that the students' average score and standard deviation rate in speaking skills on posttest improve. The students' speaking skills increased for both groups. There was a significant improvement meant shown by the experimental group, but the control group had just a bit developing. Comparing those findings indicates that students' speaking skill in the experimental group was higher than in the control group. So, the implementation of the modified British parliamentary debate model is an effective teaching model to increase the students' speaking skills.

On the other hand, the students' deviation standard of the posttest was lower than the pretest. The deviation standard of students' speaking skills decreased by 4.95 points for the students in the experimental group and 1.19 points for the students in the control group. This finding explains that the gap in students' speaking skills in the experiment is lower than in the control one.

\subsubsection{Test of Significance (t-test)}

The implementation of modified British parliamentary debate significantly increased the speaking skills of the students. It is evidenced by the t-test rate (2.087) of the posttest being higher than the t-table (2.000). This judgment is supported by an assertion by Gay et al. (2012), stating that there is a significant difference between pretest and posttest if the t-test rate is higher than the ttable rate. This condition leads to rejecting the null hypothesis $(\mathrm{H} 0)$ and accepting the alternative one $(\mathrm{H} 1)$. Therefore, based on the statements, it indicates that the use of modified British parliamentary debate can increase the speaking skill of XI grade students of MAN Enrekang.

Along with learning the modified British parliamentary debate model, the students could obtain meaningful progress in their speaking skills. The pretest results show that they made a greater mistake in terms of vocabulary, pronunciation, grammar, discourse competence, and strategic competence. It was in line with Firdaus (2012). He found that the use of the Australian 
parliamentary debate showed a good result in terms of students speaking. The improvement was in their confidence and bravery in speaking English and their vocabulary mastery. It can be seen from their language when they delivered their arguments with other students, showing their critical thinking.

Table IV-5: The rate of t-test of the students' speaking skill

\begin{tabular}{lccccl}
\hline Variables & Df & $(\boldsymbol{\alpha})$ & t-table & t-test & Remarks \\
\hline $\begin{array}{l}\text { Pretest of control and } \\
\begin{array}{l}\text { Experimental class } \\
\text { Posttest of control and }\end{array}\end{array}$ & 62 & 0.05 & 2.000 & 0.011 & $\begin{array}{l}\text { Not significantly } \\
\text { Different }\end{array}$ \\
\begin{tabular}{l} 
Experimental class \\
\hline
\end{tabular} & 62 & 0.05 & 2.000 & 2.087 & $\begin{array}{l}\text { Significantly } \\
\text { Different }\end{array}$ \\
\hline
\end{tabular}

The results showed that applying the modified British parliamentary debate model in learning could significantly increase the students' speaking skills. It means that the model was applicable in teaching speaking skills. Most of the students who participate actively in debates use modified British parliamentary debates to increase their speaking skills. It supports Diep's (2017) opinion. According to him, teachers should have flexible approaches to teaching so that the students can achieve the best results. After conducting the study, the researchers assumed that implementing the modified British parliamentary debate model in learning is one strategy to enable the students to practice their speaking skills.

In conclusion, the implementation of modified British parliamentary debate for speaking skills in the experimental group gained more significant results than in control. The results of the posttest in each component of students' speaking skills proved it. It should be noted here that the treatment brought the students into a condition that assigned them to take notes about the indistinct words and interpretations of the speaker's speech. Nevertheless, after doing the activities in modified British parliamentary debate, gradually, the students showed completion in their speaking skills. The results exhibited that after treatment, the students can speak English by implementing proper pronunciation and grammar. The treatments also enriched the students' vocabulary that made them express their idea easily. It means that the implementation of the modified British parliamentary debate model in teaching speaking provided a more significant subscription than the conventional method did. It could be inferred that the implementation of the modified British parliamentary debate model could increase the students' speaking skills

\subsubsection{The Students' Interest in learning English through the modified British parliamentary debate}

The questionnaire distributed to the experimental students contained common statements about students' interest in learning English speaking. Affirmations include interest in learning English, speaking activity in speaking class, and the willingness of students to improve speaking skills both in practice inside and outside the classroom. All affirmations are related to implementing the modified British parliamentary debate model in the experimental group by the researchers.

Some factors influence students' interest in the teaching and learning process, particularly in learning speaking skills through the modified British parliamentary debate model. They are pleasure, concern, and curiosity. While some elements associated with the modified British parliamentary debate model are seating design, determining motion, building case, conducting a debate, and adjudication role, which can establish the students' interest in learning speaking skills.

Table 2. The mean score of the students on interest toward each component of modified British parliamentary debate in learning speaking skill

\begin{tabular}{lll}
\hline No & Components & Mean Score \\
\hline 1. & Seating design & 88.41 \\
2. & Motion & 90.89 \\
3. & Case building & 89.58 \\
4. & Debate & 92.06 \\
\hline
\end{tabular}




\begin{tabular}{|c|c|c|}
\hline 5. & Adjudication & 89.19 \\
\hline Total Mean Score & & 90.03 \\
\hline
\end{tabular}

The students' pleasure (enjoyment and satisfaction)

There were ten questions formulated to evaluate the student's pleasure toward the implementation of a modified British parliamentary debate. The finding informs us that all students enjoyed and were satisfied with each component of learning speaking skills through modified British parliamentary debate. So, it could be concluded that a modified British parliamentary debate is sufficient to increase the students' speaking skills because it can add the students' pleasure in learning.

The students' concern (focuses and engages)

The rate of the students' answers related to their concerns about implementing the modified British parliamentary debate was high. It informs us that all of the students focus and can engage themselves in each component of the learning process. The researchers then inferred that the students interested in learning speaking skills modified the British parliamentary debate because it can add to their concerns about learning. Concerning the students' concern Ur (2009) stated that interest is a type of external incentive, as the district desires to learn of its shake or interest in the tasks that raise extrinsic motivation.

The students' curiosity (curious and desire)

Having seen the result of the students' questionnaire in terms of curiosity. In dictionary.com, curiosity is curiosity and desire to learn or know about anything and inquisitiveness. It informs us that all of the students are curious and desire each component of learning speaking skills through modified British parliamentary debate. Even though the percentage rate of the students' interest in terms of curiosity showed that more students answered that 'interesting' rather than 'strongly interesting,' the lesson was impressive, especially in seating design and adjudication. However, it could be inferred that the students were also interested to learn speaking skills through modified British parliamentary debates. There is none of the students chose uninterested and actively interested.

\subsubsection{The interest in the components of the modified British Parliamentary Debate.}

\section{Seating design}

The score of each interest indicated the modified British parliamentary debate in seating design showed that most of the students were strongly interested, except in curiosity. The number of students who chose interesting was more than powerfully interesting. However, overall, the students were interested to learn speaking skills through modified British parliamentary debate because of the comfortable seating design.

Motion

The rating score of the students in this component performed that the students were interested in learning speaking skills through the modified British parliamentary debate model because the motions are varied and up to date.

\section{Case building}

Based on the data describing these components, the writers inferred that the students were interested in learning speaking skills through the modified British parliamentary debate technique. The students like the ways of case building conducted because they got the opportunity to build the case before performing debate.

\section{Debate}

In line with the case building and debate component, the score of students' interest in the debate session of modified British parliamentary debate showed that the students were interested in learning speaking skills through modified British parliamentary debate.

\section{Adjudication}

Although the rating score of the students in term of curiosity in these components were only 79,69 , which is indicated as high, the other indicators' score showed very high. It means that the students were interested in learning speaking skills through modified British parliamentary debate because they got the opportunity to build the case before performing debate.

\subsubsection{The average score of the students' interest.}

The findings of the students' interest scores indicated that almost all of the students were strongly interested in learning speaking skills through the modified British parliamentary debate model. The percentage rate of the students' interest in terms of curiosity, especially in seating design and adjudication, showed that more students chose interesting rather than powerfully interesting. 
However, the writers infer that the students were interested in learning speaking skills through the modified British parliamentary debate model.

The finding was in line with Hasanah (2012) stated that the implementation of the debate could increase the students' speaking skills. The results of her research showed that the use of debate could increase students' interest and achievement. The implementation of the debate technique is reasonable because it can give students great motivation to learn speaking skills. Thus, the debate technique is useful to improve students' interest and competence in learning speaking skills.

Based on the findings above, the researchers conclude that the student's interest in learning speaking skills through modified British parliamentary debate can increase the students' achievement of speaking skills. The students' interest supports the students' success in speaking. It means that their interest in using modified British parliament debates increased the students' achievement of speaking skills.

\subsection{Pedagogical Implication}

From this research, some pedagogical implications can be reduced:

1. In teaching speaking skills, the teachers should provide an effort to make the teaching delivery more effective and efficient. The teacher should manage instruction that can involve students speaking and communicating in English by providing lively, engaging, and challenging ways of teaching.

2. Motion, topics, or materials to be taught also play essential roles in challenging students to express their ideas. The teachers, therefore, should select appropriate materials that suites the students' interest.

3. Seating design also determines students' eagerness to speak.

Therefore, the English teacher should manage the classroom in a well-organized situation. It, in turn, will felicitate the student to speak.

\section{Conclusion}

The implementation of a modified British parliamentary debate can improve the students' speaking skills at Madrasah Aliyah Negeri Baraka. The average score of the students' posttest in the experimental group, in which the researchers applied the British parliamentary debate model were higher than the conventional way in the control one. After the researchers conducted treatments, the students' mean score for the experimental group was 82,03 and for the control group was 46,20. It indicated that the students' mean score in the experimental group was higher than the control group.

Therefore, a significant difference between the posttest of control and experimental one was discovered, where the t-test rate was 2,087 is higher than the t-table standard $(2,000)$. It exhibits that the null hypothesis $(\mathrm{H} 0)$ is rejected, and the alternative hypothesis $(\mathrm{H} 1)$ is approved. It means that applying the modified British parliamentary debate model in teaching speaking can significantly contribute to learning the speaking skill. In short, the implementation of the modified British parliamentary debate technique could develop the students' speaking skills of XI grade students of MAN Enrekang.

The implementation of the modified British Parliamentary debate technique also made the students interested to learn to speak. Based on the data obtained from the questionnaires, the students' answer was categorized as strongly interested in learning to speak through the modified British parliamentary debate technique.

\section{References}

[1] Amaluddin, A, S., Mardiah. (2018). Developing Teaching Model for Listening Comprehension by using Audio Visual Aids and Metacognitive Strategy. The Asian EFL Journal. Volume 14 Issue 2. Pp. 20-32.

[2] Aziz, A., Raja Yacob, R., Suhaimin, M., Wan Ismail, W., \& Abd Razak, A. (2020). Role Play: Let's Act It Out!. International Journal Of Modern Languages And Applied Linguistics, 2(1), 32-37. doi:10.24191/ijmal.v2i1.7621

[3] Badaruddin, N, N, Jabu, B. (2019). The Potential of ICT in Blended Learning Model toward Education 4.0 Need Analysis-Based Learning Design for ELT. The Asian EFL Journal. Vol 24 Issue No 4.1. 128-142

[4] Bashir, M. (2014). Bahasa Inggris Kurikulim (2013) - Studi dan Pengajaran. Kementerian Pendidikan dan Kebudayaan. Pusat Kurikulum dan Perbukuan, Balitbang, Kemdikbud.

[5] Brown, H. D. (2001). Teaching by Principle: An Interactive Approach to Language Pedagogy. Second Edition. New Jersey: Prentical Hall Inc. 
[6] Celce-Murcia, M. (2001). Teaching English as a Second or Foreign Language, Third Edition. United State of America: Thomson Learning, Inc.

[7] D'Cuz, R. (2003). The Australia-Asia Debating Guide. Second Edition. Australian Debating Federation.

[8] Dictionary.com http://www.dictionary.com/browse/interest?s=t

[9] Diep, L. T. N. (2017). Measurement of Factors Affecting English Speaking Skills of Students at The Foreign Languages Department of Van Lang University in Vietnam. Research and Science Today; Targu-Jiu

[10] Firdaus, M. H. (2012). The Implementation of Australian Parliamentary Debate to Teach Speaking

[11] Fisher, I. (1930). The Theory of Interest. The Macmillan Company. New York.

[12] Gay, L. R. 2012. Educational Research. Competencies for Analysis and Applications. Tenth Edition. New Jersey: Pearson Education, Inc.

[13] Harmer, J. (2007) How to Teach English: An Introduction to the Practice of English Language Teaching. Edinburg Gate: Pearson Education Limited.

[14] Hasanah, U. (2012). The Implementation of Debate Technique to Improve the Students' Speaking Skills.

[15] Haycraft, J. (1978) An Introduction to English Language Teaching. Revised Impression. Longman: Longman Handbooks for Language Teachers.

[16] Heaton, J.B. (1990). Writing English Language Test. New Edition.Longman Handbooks for Language Teachers. London and New York.

[17] Hidi, S. \& Renninger, K. (2006). The Four-phase Model of Interest Development. Educational Psychologist, (online), 41, 111-127. Accessed at http://jlls.org/lssues/Volume1 /No.2/nazligunduz.pdf, 6

[18] Hornby, A.S. (2010). Oxford Advanced Learner's Dictionary, New Oxford 3000TM vocabulary Trainer. Oxford: Oxford University Press.

[19] Irona, A, and Ratmanida. (2018). Using Information Gap Activity in Classroom Interaction to Increase the Students' Speaking Ability. Journal of English Language Teaching. 7(1): 216-223.

[20] Ismaili, M, and Bajrami, L. (2016). Information Gap Activities to Enhance Speaking Skills of Elementry Level Students. Procidia Social and Behavioral Science. 232; 612-616. https://doi.org/10.1016/j.sbspro.2016.10.084

[21] James, A. (2003). The Database Book. A Must-Have Guide For Successful Debate. The International Debate Education Association. New York: Idea Press Books.

[22] Latifa, A; Rahman, A; Hamra, A; Jabu, B.; Nur, R. (2015). Developing a Practical Rating Rubric of Speaking Test for University Students of English in Parepare, Indonesia. Vol 8, No.6 http://www.ccsenet.org/journal/index.php/elt/article/view/49419.

[23] Latifa, A; Nur, R; Amaluddin. (2019). Utilizing Google Classroom Application to Teach Speaking to Indonesian EFL Learners. The Asian EFL Journal. Vol 24 Issue No 4.1.

[24] McCharthy, M. (2000). Discourse Analysis for Language Teachers. Tenth Printing. Cambridge: CambridgeUniversity Press

[25] Morgan, G R. (2011). British Parliamentary Debate. Stylus Communication.

[26] Nur, R and Syarifuddin, R. (2018). Designing an Instructional Model of YouTube-Based Materials of Listening Comprehension at Umpar Indonesia. The Asian EFL Journal. Vol 20 issue 7. Pp 94-108.

[27] Oradee, T. (2012). Developing Speaking Skills Using Three Communicative Activities (Discussion, Problem-Solving, and Role-Playing) International Journal of Social Science and Humanity; Singapore2.6

[28] Richard, J. C., and Rodger, T. S. (1999). Approaches and Method in Language Teaching: Communicative Language Teaching. Cambridge: Cambridge University Press

[29] Smith, N. H. (2011). The Practical Guide to Debating World Style/British Parliamentary Debate. International Debate Education Association. New York: I debate Press.

[30] Sugiono. (2013). Metode Penelitian Kuantitatif Kualitatif dan R\&D. Bandung: Penerbit Alfabeta.

[31] Supharatypthin, D. (2014). Developing Students' Ability in Listening and Speaking English Using the Communicative Approach of Teaching. International Journal of Arts \& Sciences;

[32] Thai. (2018). An Investigation into some factors Influencing to Student's Motivation to Learn Speaking English of the First-Year Students, at English Department, University of Foreign Language Studies - Danang University - Vietnam. The Asian EFL Journal. Vol 20 issue 7. 81-87.

[33] Tillit B., Bruder. M. N. (1993). Speaking Naturally: Communication Skills in American English. Seventh Print. Cambridge: Cambridge University press

[34] Walter, E. (2008). Cambridge Advanced Learner's Dictionary, (Electronic Dictionary) Third Edition. Cambridge: Cambridge University Press

[35] Widdowson, H.G. (1978). Teaching Language as Communication. Oxford University Press.

[36] Yule, G. (2006). The Study of Language. Third Edition. Cambridge University Press. 